\title{
A new species of Potamonautes from São Tomé Island, Central Africa, with redescriptions of $P$. margaritarius (A. Milne-Edwards, 1869) from São Tomé, and P. principe Cumberlidge, Clark and Baillie, 2002, from Príncipe (Decapoda: Potamonautidae)
}

\author{
Neil Cumberlidge ${ }^{1,3}$, Savel R. Daniels ${ }^{2}$ \\ ${ }^{1}$ Department of Biology, Northern Michigan University, 1401 Presque Isle Ave, Marquette, MI 49855, USA. \\ ${ }^{2}$ Department of Botany and Zoology, University of Stellenbosch, Private Bag X1, Matieland 7602, South Africa. \\ ${ }^{3}$ E-mail: ncumberl@nmu.edu
}

Keywords: freshwater crab, taxonomy, Gulf of Guinea islands, P. saotome sp. nov., neotype

\begin{abstract}
Surveys of the freshwater crabs of two islands in the Gulf of Guinea, Central Africa, allowed a revision of the taxonomy of two little-known island endemic species, based for the first time on adult males: Potamonautes margaritarius (A. Milne-Edwards, 1869) from São Tomé, and of $P$. principe Cumberlidge, Clark and Baillie, 2002, from Príncipe (Brachyura; Potamonautidae). A new species of Potamonautes from southern São Tomé (Potamonautes saotome sp. nov.) is also described that is genetically distinct and has a clearly separate geographic distribution from P. margaritarius from northern São Tomé. The new species from southern São Tomé can be recognized by a suite of characters of the carapace, thoracic sternum, and gonopods. The taxonomy of P. margaritarius (A. Milne-Edwards, 1869) is stabilized by selecting a neotype from northern São Tomé. Potamonautes principe from Príncipe is the most distinct of the three taxa, with a more swollen carapace that has smooth anterolateral margins, and a shorter, straighter male first gonopod. All three taxa are morphologically distinct species that have also been clearly distinguished as evolutionarily separate lineages by mtDNA analysis and haplotyping in an earlier study. Previous phylogenetic evidence supports two separate island colonization events at different times in the past from different ancestral populations, one to São Tomé and another to Príncipe that resulted in the establishment of the endemic freshwater crab faunas of these two islands.
\end{abstract}

\section{Contents}

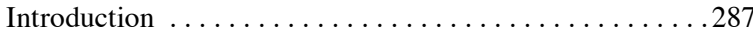

Material and methods . . . . . . . . . . . . . . . . . . . . . . . 289

Results. . . . . . . . . . . . . . . . . . . . . . . . . . . . . 289

Taxonomy . . . . . . . . . . . . . . . . . . . . . . . 290

Potamonautes margaritarius (A. Milne-Edwards,

1869) . . . . . . . . . . . . . . . . . . . . . . . . . . 291

Potamonautes saotome sp. nov........... . . . . 295

Potamonautes principe Cumberlidge, Clark and

Baillie, 2002.
Discussion. .......................... 300

Habitat and ecology. . . . . . . . . . . . . . . . . . . 300

Biogeographic considerations. . . . . . . . . . . . 300

Acknowledgements. . . . . . . . . . . . . . . . . 301

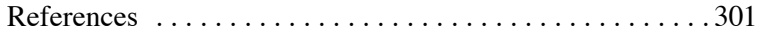

\section{Introduction}

We report here on the results of biotic surveys of the freshwater crabs of two remote tropical Atlantic islands (São Tomé and Príncipe) that lie in the Gulf of Guinea off the coast of Central Africa. The surveys produced 150 specimens of freshwater crabs all in the genus Potamonautes, 106 from São Tomé and 44 from Príncipe. São Tomé and Príncipe are two of a chain of four volcanic Gulf of Guinea islands (the others being Bioko and Annobón) (Measey et al., 2007; Bell et al., 2015). These four islands are part of the Cameroon Volcanic Line that also produced Mount Cameroon and a series of other volcanic mountains in Western Cameroon (Table 1). Bioko is the largest $\left(2,017 \mathrm{~km}^{2}\right)$, youngest $(0.01 \mathrm{MY})$, and closest $(100 \mathrm{~km})$ of the four islands to mainland Africa and was formerly a peninsula of Cameroon that became isolated during the Holocene as a consequence of rising sea levels and was last connected to the mainland about 12,000 years ago (Juste and Fa, 1994). This history is reflected in Bioko's freshwater crab fauna that comprises two species of Sudanonautes (S. granulatus (Balss, 1929) and S. floweri (De Man, 1901)) both of which are also found on the nearby mainland in Nigeria and Cameroon (Cumberlidge, 1999, 2008a). The other three islands, São Tomé, Príncipe, and Annobón are completely isolated in the Atlantic Ocean from each other and from the African mainland, having never been connected 


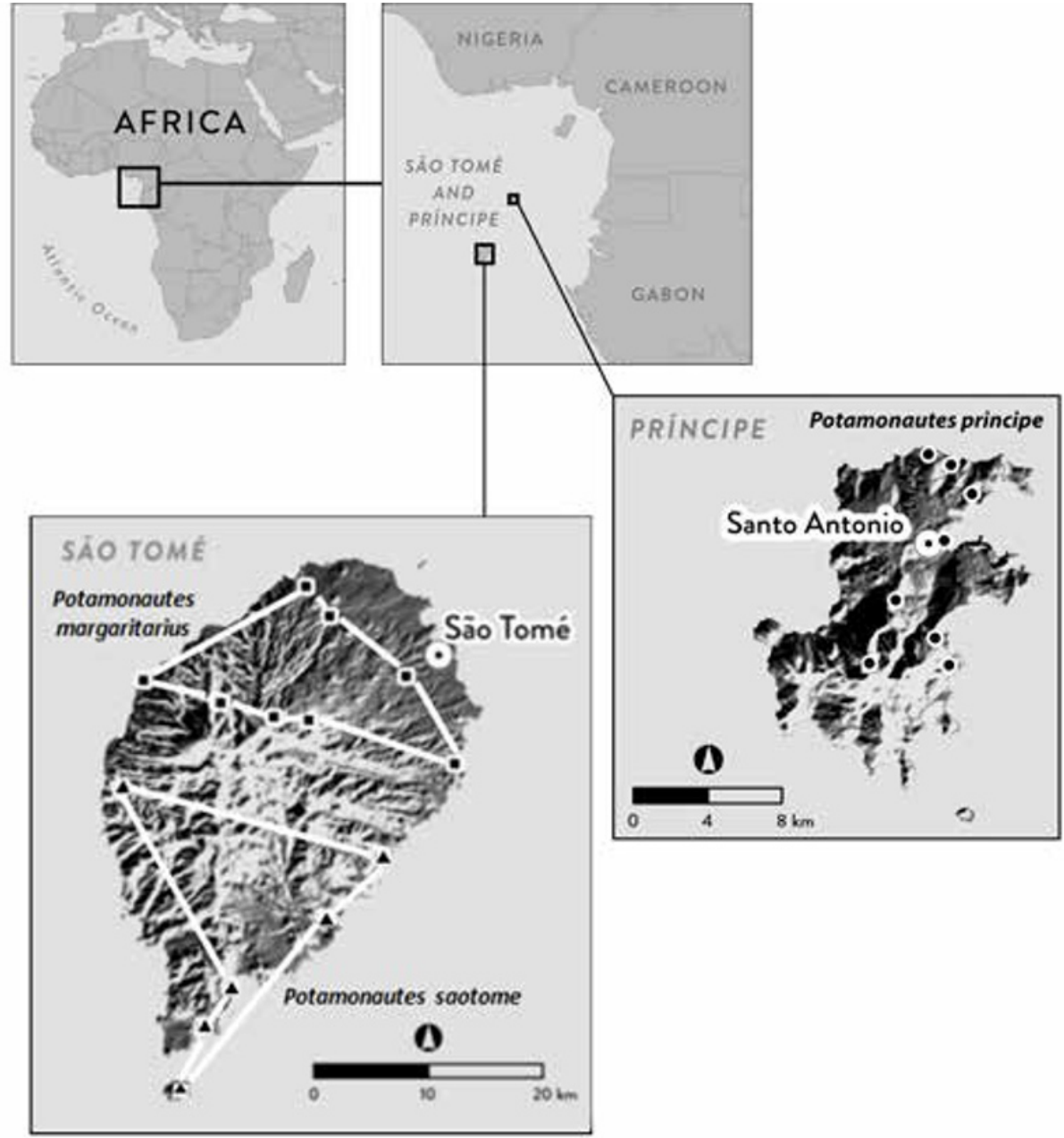

Figure 1. Distribution map showing the known localities of Potamonautes margaritarius (black squares, not shown to scale) in northern São Tomé Island; Potamonautes saotome sp. nov. (black triangles, not shown to scale) in southern São Tomé Island, and Potamonautes principe (black circles, not shown to scale) in Príncipe Island. For exact localities see text. to continental Africa (Juste and Fa, 1994) (Table 1). Annobón Island is the furthest south, the furthest from the African mainland $(335 \mathrm{~km})$, the smallest $\left(17 \mathrm{~km}^{2}\right)$, and the youngest (4.8 MY) of this island chain (Lee et al., 1994), and there are no reports of freshwater crabs from there (Cumberlidge, 2008a). São Tomé $\left(836 \mathrm{~km}^{2}\right)$ lies $240 \mathrm{~km}$ from the African mainland, is between 15.7 to $13.1 \mathrm{MY}$ old (Lee et al., 1994), and hosts a single endemic species of freshwater crab (Potamonautes margaritarius (A. Milne-Edwards, 1869)) (Cumberlidge, 2008a). Finally, Príncipe (128 $\mathrm{km}^{2}$ ) is the oldest of these three islands (31 MY), lies $225 \mathrm{~km}$ from the African mainland, and hosts a single endemic species of freshwater crab (Potamonautes principe Cumberlidge, Clark and Baillie, 2002).

The freshwater crabs of these islands are not well known and very few specimens have been reported in the 149 years since they were first discovered on São Tomé (A. Milne-Edwards, 1869), with the presence of freshwater crabs on Príncipe first established only in 2002 (Cumberlidge et al., 2002). It is not surprising, therefore, that the first comprehensive survey of these two islands by the second author in 2017 (Daniels and Klaus, 2018) produced a total of 150 specimens and 21 new locality records, including a new species from São Tomé that is described here. Daniels and Klaus (2018) focused on the phylogeography of $P$. margaritarius and $P$. principe and used two mitochondrial markers (CO1 and $16 \mathrm{~S}$ ) and one nuclear marker (h3) to investigate the evolutionary lineages within the freshwater crab faunas of both São Tomé and Príncipe. The molecular investigations of the crabs from São Tomé (Daniels and Klaus, 2018: fig. 3 ) revealed that $P$. margaritarius may comprise two genetically distinct species but those authors indicated that a morphological study was needed to investigate this. Geographically, one of the São Tomé species (P. margaritarius) is found only in the north of the island, while the other one (P. saotome 
sp. nov.) is restricted to the south of the island (Fig. 1). The molecular investigations of the new material from Príncipe (Daniels and Klaus, 2018: fig. 5) indicated that all specimens belonged to a single lineage that is represented by $P$. principe.

Here we describe the new species of freshwater crab from São Tomé, and redescribe $P$. margaritarius and $P$. principe based on the results of a detailed comparative morphological study of the specimens from these two different Gulf of Guinea islands. Both P. margaritarius and $P$. principe were originally described from female specimens (A Milne-Edwards, 1869; Cumberlidge et al., 2002) so our redescriptions provide first-time accounts of the taxonomically important characters of the male gonopods, sternum, and chelipeds of both $P$. principe and $P$. margaritarius. The redescription of the latter species is necessary because although Bott's (1955) description of $P$. margaritarius was based on an adult male, he only sketched part of the first gonopod of a non-type specimen. Finally, new data on the habitat at each of the 21 new localities, as well as updated distribution maps of these three oceanic island species are provided, and their conservation status is discussed in the light of the new data provided here.

\section{Material and methods}

One hundred and fifty specimens of Potamonautes from 21 new localities were collected by the second author from São Tomé (between July $3^{\text {rd }}$ and $7^{\text {th }}, 2017$ ) and Príncipe (between July $14^{\text {th }}$ and $18^{\text {th }}, 2017$ ) (Daniels and Klaus, 2018: table 1). Crabs on both islands were always associated with freshwater habitats (either streams or rivers) and were typically semi-terrestrial, either living on land, in burrows near water, or under rocks in streams. All specimens were preserved in $100 \%$ ethanol. Most of the collection localities were in either closed canopy primary forest, secondary forest, or on disturbed land (altered for agriculture or for rural and urban development). Morphological analyses, consisting of a detailed examination of characters of the carapace, thoracic sternum, mouthparts, chelipeds, and gonopods, were carried out on each specimen. The geographic range of each species was estimated using the extent of occurrence (EOO) (the area contained within the minimum convex polygon around all sites of present occurrence) and/or the area of occupancy (AOO) (the area within the EOO that is actually occupied by the taxon, estimated by overlaying a $2 \mathrm{x}$ $2 \mathrm{~km}$ grid and summing the area of occupied cells).
GeoCAT (Bachman et al., 2011) was used to calculate $\mathrm{EOO}$ and $\mathrm{AOO}$ measurements from point locality data. Details of the molecular analyses and results are given in Daniels and Klaus (2018: figs. 2, 3). Specimens are deposited in the Iziko South African Museum, Cape Town, South Africa (SAM). All measurements were made with digital calipers and are given in millimetres. Abbreviations used: a1-a6, pleonal (abdominal) somites 1-6; asl, above sea level; CAS-IZ, California Academy of Science, Invertebrate Zoology collection, San Francisco, USA; cw, distance across the carapace at the widest point; cws, plural of $\mathrm{cw}$; ch, carapace height, the maximum height of the cephalothorax; $\mathrm{cl}$, carapace length, the distance between the central lobe of the frontal margin and the posterior margin of the carapace; coll., collected by; fw, front width measured between the two lateral lobes of the front; all measurements in $\mathrm{mm}$; e, thoracic episternite; G1, first gonopod (= first pleopod of male); G2, second gonopod (= second pleopod of male); juv., juvenile; ovig., ovigerous; MNHN, Museum national d'Histoire naturelle, Paris, France; MY, million years; MYA, million years ago; p1-p5, pereiopods $1-5 ; \mathrm{s}$, thoracic sternite; s1/s2, s2/ s3, s3/s4, sternal sutures between adjacent thoracic sternites; SMF, Senckenberg Museum, Frankfurt, Germany; SS, subterminal segment of G1 or G2; TA, terminal article of G1 or G2; ZIM, Zoological Institute and Museum, Hamburg, Germany; ZMB, Museum für Naturkunde, Berlin, Germany; ZSM, Zoologische Staatssammlung München (the Bavarian State Collection of Zoology), Germany. The terminology is adapted from Cumberlidge (1999) and the higher classification used follows that of $\mathrm{Ng}$ et al. (2008). The habitus photographs were taken by Theo Busschau, Stellenbosch University, South Africa. Post processing of the figures was done using Adobe Photoshop CC 2015.0.1 Release.

\section{Results}

Careful comparison of the taxonomically significant morphological characters of the carapace, sternum, mouthparts and gonopods, together with distinct genetic differences, yielded evidence to warrant the redescription of $P$. margaritarius, the recognition of a new species from São Tomé, and the redescription of $P$. principe from Príncipe. The 106 specimens of freshwater crabs from São Tomé that diverged into two monophyletic lineages or clades (Daniels and Klaus, 2018: fig. 2) were found to form two morphologically 


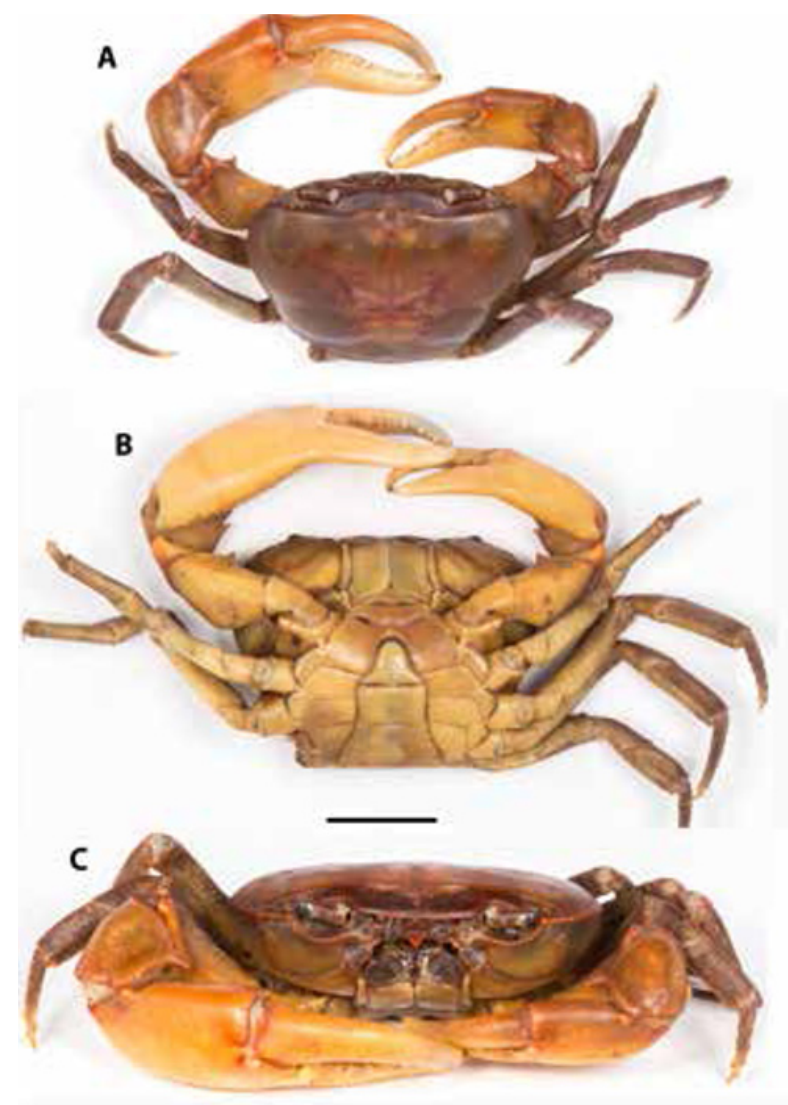

Figure 2. Potamonautes margaritarius. Adult $\widehat{\partial}, \mathrm{cw} 45.6 \mathrm{~mm}$ (SAM-A090176) from Santana, São Tomé, in the Democratic Republic of São Tomé and Príncipe. A, whole animal, dorsal view; $\mathrm{B}$, whole animal, ventral view; $\mathrm{C}$, whole animal, frontal view. Photographs by Theo Busschau, Stellenbosch University, South Africa.

distinct groups, one that is exclusively from the north of the island that includes the nominal species $P$. margaritarius, and one that is exclusively from the south of the island that is described here as P. saotome sp. nov. (present study; Daniels and Klaus, 2018: fig. 3). This division is also supported by the haplotype network for the freshwater crabs from São Tomé (see Daniels and Klaus, 2018: fig. 5) that contained 14 haplotypes (nine exclusive for $P$. margaritarius in the north of the island and five exclusive for $P$. saotome sp. nov in the south of the island) and was congruent with the phylogenetic analyses in that it also retrieved the same well-supported group. The 44 specimens of freshwater crabs from Príncipe were used to redescribe the species because they were all
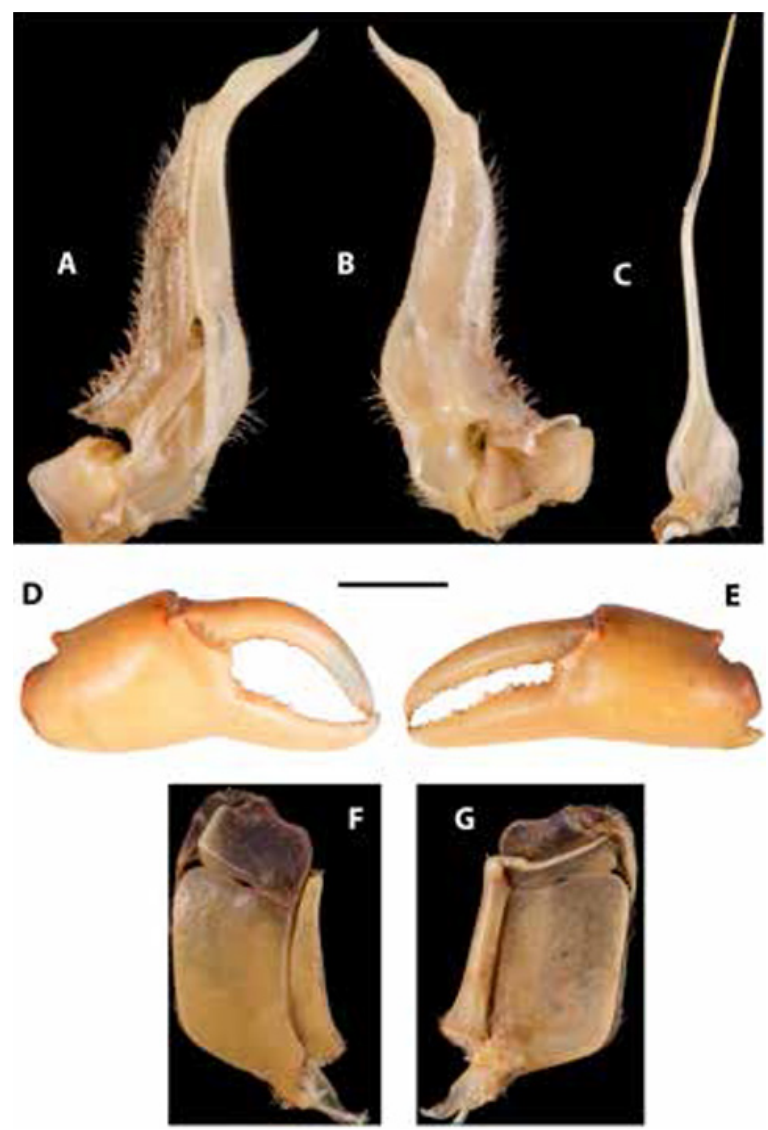

Figure 3. Potamonautes margaritarius. Adult §ิ, cw $45.6 \mathrm{~mm}$ (SAM-A090176) from Santana, São Tomé, in the Democratic Republic of São Tomé and Príncipe. A, left G1 ventral view, B left G1 dorsal view, C, G2 left ventral view. D, right cheliped, frontal view; E, left cheliped, frontal view; G, left third maxilliped, frontal view; $\mathrm{H}$, left third maxilliped, posterior view. Photographs by Theo Busschau, Stellenbosch University, South Africa. Scale bar $3.4 \mathrm{~mm}(\mathrm{~A}-\mathrm{C}), 17.4 \mathrm{~mm}(\mathrm{D}, \mathrm{E}), 4 \mathrm{~mm}(\mathrm{~F}-\mathrm{H})$.

included in a single monophyletic clade that represents $P$. principe. The haplotype network for the freshwater crabs from Príncipe (see Daniels and Klaus, 2018: fig. 5) contained seven haplotypes for $P$. principe and was congruent with the phylogenetic analyses in that it also retrieved a single well-supported group.

\section{Taxonomy}

Infraorder BRACHYURA Latreille, 1802

Superfamily POTAMOIDEA Ortmann, 1896

Family POTAMONAUTIDAE Bott, 1970

Subfamily POTAMONAUTINAE Bott, 1970

Genus Potamonautes MacLeay, 1838 
Potamonautes margaritarius (A. Milne-Edwards, 1869) (Figs. 1, 2, 3, Tables 1, 2)

Thelphusa margaritaria A. Milne-Edwards, 1869: 185, pl. 9 fig. 4, figs. 4a-b.

Telphusa perlata. Brito-Capello, 1871: pl. 2, fig. 12 [not A. Milne-Edwards].

Thelphusa margaritaria. Greef, 1882: 37; Greef, 1884: 54; A. Milne-Edwards, 1886: 150; A. Milne-Edwards, 1887: 130; Ozorio, 1887: 221; Ozorio, 1889: 129, 132; Ozorio, 1892: 199.

Potamon (Potamonautes) margaritarium. Ortmann, 1897: 304, 308; Rathbun, 1900: 283.

Potamon (Potamonautes) margaritarius. Rathbun, 1904: pl. 14, fig. 10; Rathbun, 1905: 168-169.

Thelphusa margaritaria. Ozorio, 1905: 149.

Potamon (Potamonautes) margaritarius. De Man, 1914: 135.

Potamon margaritarius. Chace, 1942: 216.

Potamonautes (Platypotamonautes) margaritarius. Bott 1955: 229, 235, pl. XXX, figs. la-d, 11.

Potamonautes margaritarius. Balss, 1914: 102; Ng, Guinot, Davie, 2008: 171; Cumberlidge, 2008a: 72, 77, table 1; Cumberlidge, 2011: 79, 82-83 tables 6.1, 6.3 .

Type specimen. Neotype (here designated). São Tomé Island, Democratic Republic of São Tomé and Príncipe. ô adult (cw 45.6, cl 32.6, ch 14.4, fw 14.4 mm) (SAM-A090176), Santana (0.2512 N, 6.740567 E), $55 \mathrm{~m}$ asl, coll. S. R. Daniels and T. Busschau, 4.vii.2017.

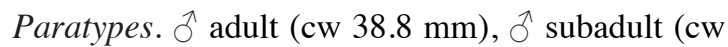
$34.5 \mathrm{~mm}$ ), 5 우 0 adults (cws 43.0, 38.4, 38.3, 38.1, 37.2 ovigerous) (SAM-A090177), Santana (0.2512
N, 6.740567 E), $55 \mathrm{~m}$ asl, coll. S. R. Daniels and T. Busschau, 4.vii.2017. $q$ adult (cw $42.7 \mathrm{~mm}), 3 q$ subadults (cws 35.4, 33.7, $19.1 \mathrm{~mm}$ ) (SAM-A090178), Santana A (0.2512 N, 6.740567 E), $55 \mathrm{~m}$ asl, from a cocoa plantation, in bank of shallow stream under larva rocks and boulders, coll. S. R. Daniels and T. Busschau, 3.vii.2017.2 §ో adults (cws 40.0, $36.6 \mathrm{~mm}$ ) (SAM-A090178), Santana B (0.2512 N, 6.740567 E), $44 \mathrm{~m}$ asl, coll. S. R. Daniels and T. Busschau, 5.vii.2017.

Type of Thelphusa margaritaria A. Milne-Edwards, 1869, , subadult, cw 33, cl 27, fw $10.8 \mathrm{~mm}$ (MNHNIU-2000-4361 (= MNHN-B4361)), São Tomé Island, date and coll. unknown is designated here as a nomen dubium. This dried specimen was part of a collection of crustaceans and arachnids sent to the Muséum national d'Histoire naturelle, Paris in 1869 by Mr Barboza $\mathrm{du}$ Bocage, director of the the Museu Nacional de História Natural e da Ciência, Lisbon. This specimen was examined by the first author.

Material examined. São Tomé Island, Democratic Republic of São Tomé and Príncipe. $7 \widehat{\partial} \hat{\partial}$ subadults (cws 29.7, 23.6, 24.5, 22.8, 22.6, 19.2, $17.5 \mathrm{~mm}$ ), ㅇ subadult (cw $31.2 \mathrm{~mm}$ ) (SAM-A090179), São Nicolau, waterfall $(0.28565 \mathrm{~N}, 6.625767 \mathrm{E}), 918 \mathrm{~m}$ asl, coll. S. R. Daniels and T. Busschau, 4.vii.2017. $\delta$ subadult (cw $27.8 \mathrm{~mm}$ ), $3 \circ+$ adults (cws 40.6, 38.5, $36.1 \mathrm{~mm}$ ), 2 우 subadults (cws 30.7, 30.0 mm) (SAM-A090180), at Lagoa Amelia River above the Botanical Gardens (0.288117 N, 6.598233 E), $1.275 \mathrm{~m}$ asl, coll. S. R. Daniels and T. Busschau, 4.vii.2017. $4 \hat{\jmath}$ subadults (cws 25.4, 25.3, 24.2, 14.3 mm), + adult (cw $39.8 \mathrm{~mm}$ ), o subadult (cw $33.7 \mathrm{~mm}$ ), plus detached carapace (cw $41.7 \mathrm{~mm}$ ) (SAM-A090181), on the road to São Tomé City (0.320217 N, 6.702183 E), $121 \mathrm{~m}$ asl, coll. S. R.

Table 1. Comparison of the age, area, and distance from the African mainland of the four Gulf of Guinea Islands, and the species of freshwater crabs found there.

\begin{tabular}{|c|c|c|c|c|c|}
\hline Country & Island & $\begin{array}{l}\text { Age } \\
(\mathrm{MY})\end{array}$ & $\begin{array}{l}\text { Area } \\
\left(\mathrm{km}^{2}\right)\end{array}$ & $\begin{array}{l}\text { Distance from } \\
\text { Mainland (km) }\end{array}$ & $\begin{array}{l}\text { Freshwater crab } \\
\text { species }\end{array}$ \\
\hline Equatorial Guinea & Bioko & 0.01 & 2,017 & $\begin{array}{c}\text { Nigeria: 100; } \\
\text { Equatorial } \\
\text { Guinea: } 160\end{array}$ & $\begin{array}{l}\text { Sudanonautes floweri, } \\
\text { S. granulatus }\end{array}$ \\
\hline Democratic Republic of São Tomé \& Príncipe & Príncipe & 31 & 128 & 225 & Potamonautes principe \\
\hline Democratic Republic of São Tomé \& Príncipe & São Tomé & $15-13$ & 834 & 240 & $\begin{array}{l}\text { P. margaritarius, } \\
\text { P. saotome sp. nov. }\end{array}$ \\
\hline Equatorial Guinea & Annobón & 4.8 & 17 & 335 & none \\
\hline
\end{tabular}


Table 2. List of museum material of Potamonautes margaritarius s. 1. examined. Tentative identifications of the five specimens with locality information are based on whether it was collected from the northern or southern part of the island of São Tomé. See text for museum abbreviations.

\begin{tabular}{|c|c|c|c|c|}
\hline Island & Locality, Habitat & Museum Cat. No. & Collector/Date & $\begin{array}{l}\text { Georeference / Identification on } \\
\text { Geographical Evidence }\end{array}$ \\
\hline São Tomé & $\begin{array}{l}\text { Between Santa Louisa } \\
\text { and Santa Adelaide, } \\
\text { northern São Tomé: } \\
\text { 'Potamonautes 2' in } \\
\text { Daniels et al. (2015) }\end{array}$ & $\begin{array}{l}\text { CAS-IZ 188789.00, } \\
\text { female }\end{array}$ & JP Pio and RB Bell, 2012 & $\begin{array}{l}0.27939 \text { N, } 6.64637 \text { E, } \\
\text { northern São Tomé, probably } \\
\text { Potamonautes margaritarius }\end{array}$ \\
\hline São Tomé & $\begin{array}{l}\text { Shallow streams, } \\
\text { stream banks, under } \\
\text { stones \& leaves }\end{array}$ & SMF 23251 & $\begin{array}{l}\text { Unknown, } 19.07 .1989 \text { to } \\
\text { 06.ix.1989 }\end{array}$ & $\begin{array}{l}0.322573 \text { N, } 6.712444 \text { E, } \\
\text { northern São Tomé, probably } \\
\text { Potamonautes margaritarius }\end{array}$ \\
\hline São Tomé & Boa Entrada & ZIM K-15053 & Unknown & $\begin{array}{l}0.351437 \text { N, } 6.663449 \mathrm{E} \\
\text { northern São Tomé, probably } \\
\text { Potamonautes margaritarius }\end{array}$ \\
\hline São Tomé & $\begin{array}{l}\text { Mountain stream in } \\
\text { forest near Lagoa } \\
\text { Almela, } \sim 1,000 \mathrm{~m} \text { asl }\end{array}$ & ZMB 26614 & R Gunther, 14.vi.1983 & $\begin{array}{l}0.079222 \mathrm{~S}, 6.543515 \mathrm{~N}, \\
\text { southern São Tomé, probably } \\
\text { Potamonautes saotome sp. nov. }\end{array}$ \\
\hline São Tomé & Islas das Rolas & ZIM-K-3548 & H Greef, 24.vii.1901 & $\begin{array}{l}0.00715 \text { S, } 6.522402 \text { E, } \\
\text { southern São Tomé, probably } \\
\text { Potamonautes saotome sp. nov. }\end{array}$ \\
\hline São Tomé & Unknown & SMF 2657 & T Monod, 17.viii.1956 & Species assignment uncertain \\
\hline São Tomé & Unknown & $\begin{array}{l}\text { MNHN- } \\
\text { IU-2000-4361 (= } \\
\text { MNHN-B4361). } \\
\text { Type, subadult } \\
\text { female }\end{array}$ & Barboza du Bocage, 1869 & Species assignment uncertain \\
\hline São Tomé & Unknown & ZSM 1196/1 & Connbra & Species assignment uncertain \\
\hline São Tomé & Unknown & ZIM K-3549 & $\begin{array}{l}\text { H Greef, Inner Afrika } \\
\text { Expedition des Herzogs Friedr. } \\
\text { z. Mecklenberg, 18.xii.1885 }\end{array}$ & Species assignment uncertain \\
\hline São Tomé & $\begin{array}{l}\text { Stream in primary } \\
\text { forest, unknown } \\
\text { locality }\end{array}$ & $\begin{array}{l}\text { ZIM-K-5374. } \\
\text { Female. }\end{array}$ & $\begin{array}{l}\text { A Schubotz, Inner Afrika } \\
\text { Expedition des Herzogs Friedr. } \\
\text { z. Mecklenberg, } 1910\end{array}$ & Species assignment uncertain \\
\hline
\end{tabular}

Daniels and T. Busschau, 4.vii.2017. $\widehat{\jmath}$ adult (cw 39.2 $\mathrm{mm}$ ), 7 đ઼ subadults (cws 32.3, 28.3, 27.1, 25.6, 23.6, 22.1,21.2 mm), 3 q subadults (cws 26.5, 22.4, 20.6 mm) (SAM-A090183), Cascata Agustino Neto (0.36745 N, $6.6422 \mathrm{E}$ ), $189 \mathrm{~m}$ asl, coll. S. R. Daniels and T.

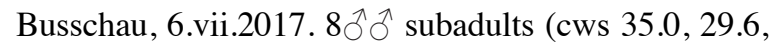
$29.8,25.3,18.5,16.8,18.2,15.8 \mathrm{~mm}), 4 ㅇ ㅜ$ 우 subadults (cws 35.2, 28.8, 20.3, $19.0 \mathrm{~mm}$ ) (SAM-A090184), Cascata Nazare A, waterfall above Neves (west coast) (0.300517 N, 6.554017 E), $766 \mathrm{~m}$ asl, coll. S. R. Daniels and T. Busschau, 6.vii.2017. ô adult (cw $38.0 \mathrm{~mm}$ ), 8 ऊ̂े subadults (cws 25.6, 25.2, 19.7, 14.1,
22.7, 18.9, 19.2, $16.7 \mathrm{~mm})$, subadult (cw $30.8 \mathrm{~mm}$ ) (SAM-A090185), Cascata Nazare B, waterfall above Neves (west coast), (0.299267 N, 6.556533 E) 614 m asl, coll. S. R. Daniels and T. Busschau, 6.vii.2017. $\hat{\sigma}$ adult (cw $36.6 \mathrm{~mm}$ ), $2 \hat{\jmath} \hat{\jmath}$ subadults (cws 31.7, $22.9 \mathrm{~mm}$ ), 2우 subadults (cws 26.8, $21.8 \mathrm{~mm}$ ) (SAM-A090186), Diogo Vaz (0.3169 N, 6.495967 E), $62 \mathrm{~m}$ asl, coll. S. R. Daniels and T. Busschau,

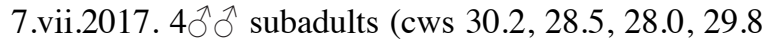
$\mathrm{mm}$ ), ㅇ subadult (cw $25.4 \mathrm{~mm}$ ) (SAM-A090182), Guadalupe (0.39085 N, 6.623567 E), $76 \mathrm{~m}$ asl, coll. S. R. Daniels and T. Busschau, 7.vii.2017. 
Diagnosis. Adult male. Thoracic sternal sulcus s3/s4 deep, V-shaped, meeting anterior rim of sternopleonal cavity, but not cavity itself, completely crossing thoracic sternum (Fig. 2B); third maxilliped ischium smooth, lacking conspicuous vertical sulcus (Fig. 3G); cheliped merus with large pointed subdistal meral tooth otherwise lower margins smooth (Fig. 2B); G1 TA short (TA/SS 0.48), slim, basal third straight, curving outward at 45 degree angle to axis of gonopod, midsection widened medially on dorsal side, tip (terminal third) slightly upcurved (Figs. 3A-B).

Redescription. Carapace (Figs. 2A-C): surface smooth; flat (ch/fw 1.0); postfrontal crest distinct, completely crossing carapace; exorbital, epibranchial teeth each reduced to small granule; anterolateral margin granulated between exorbital, epibranchial teeth, and behind epibranchial tooth; semicircular, urogastric, cardiac, branchial grooves deep; cervical groove deep near semicircular groove, fading toward postfrontal crest; groove between epigastric crests long, forked posteriorly; front broad (fw/cw 0.32); branchiostegal wall divided by pleural (vertical) suture, epimeral (longitudinal) suture into three regions, all smooth; suborbital margin granulated. Mandible: palp two-segmented; terminal segment simple. Third maxilliped (Figs. 3G-H): exopod with long flagellum, ischium smooth lacking sulcus. Epistomial tooth large, triangular, margins lined by granules. Thoracic sternum (Fig. 2B): s2/ s3 deep, horizontal, completely crossing sternum; s3/s4 deep, V-shaped, meeting anterior rim of sternopleonal cavity, but not cavity itself; margins of s4 low, not raised. Cheliped (Figs. 2D-E): dactylus (moveable finger) slim, highly arched, enclosing oval interspace, one large tooth medially, otherwise teeth small; propodus (fixed finger) with four large molars proximally; carpus distal tooth large, pointed, proximal tooth subequal, pointed; merus inferior margins both smooth, distal meral tooth large, pointed; p2-p5 slim. Pleon (Fig. 2B): wide, triangular, telson (a7) triangular, with rounded apex, indented sides. Gonopods (Figs. 3A-C): G1 TA: short (TA/SS 0.48), slim, basal third slim, straight, curving outward at 45 degree angle to axis of gonopod, midsection widened dorsally, tip (terminal third) slightly upcurved; G2 TA: long (TA/SS 0.68), flagellum-like. Adults (judged by size at pubertal moult) beginning around cw $36 \mathrm{~mm}$ in both sexes.

Coloration. Dorsal carapace, branchiostegal walls light brown, cheliped dactylus, propodus white except for light brown dorsal margin, thoracic sternum cream.
Distribution. Potamonautes margaritarius is endemic to the northern part of São Tomé Island from low lying areas around $44 \mathrm{~m}$ asl to higher ground inland (up to 1,275 $\mathrm{m}$ asl). The known distribution of this species is shown in Fig. 1. The map is based on the georeferenced localities of the relevant specimens collected by Daniels and Klaus (2018: table 1, fig. 1) from São Tomé, and also includes museum specimens from São Tomé Island, and literature records.

Ecological notes. Potamonautes margaritarius occurs in clear water streams where it lives under boulders, in burrows dug into the banks of streams and rivers, under stones in damp places, and out of the water among vegetation. The recorded locations are in lowland forest, secondary forest, and montane forest. The highest elevation at which P. margaritarius has been collected (by R. Gunther in June 1983) is from Lagoa Amelia $(0.283377 \mathrm{~N}, 6.600081 \mathrm{E})(1,339 \mathrm{~m}$ asl), a crater lake in the montane forest in the center of the island in Ôbo National Park.

Haplotype. The specimens assigned to $P$. margaritarius in this study correspond to the Northern clade in the maximum clade credibility tree for $P$. margaritarius s. 1. based on $102 \mathrm{CO} 1$ sequences shown in Daniels and Klaus (2018: fig. 3), and contains all individuals from the northern part of São Tomé.

Conservation status. Potamonautes margaritarius was listed as least concern (LC) on the International Union for the Conservation of Nature Red List (Cumberlidge, 2008b; Cumberlidge et al., 2009) in view of its island-wide distribution (which was then understood to be throughout São Tomé island), estimated stable population size, lack of known widespread long-term threats, and its presence in a protected area in at least part of its range (the Ôbo National Park) (Cumberlidge et al., 2009). The Ôbo National Park of São Tomé and Príncipe covers 235 $\mathrm{km}^{2}$ of the south of São Tomé Island and this same park is also found on Príncipe where it occupies $65 \mathrm{~km}^{2}$ of the island. Potamonautes margaritarius is endemic to the northern parts of São Tomé and has been recorded from more than ten localities at different altitudes from 44 to 1,275 $\mathrm{m}$ asl. The revised distribution of $P$. margaritarius is shown in Fig. 1 and is based on the literature (Table 2), and on georeferenced localities of a subset of the specimens collected by Daniels and Klaus (2018: table 1). Our taxonomic conclusions mean that $P$. margaritarius has a reduced range because it no longer occurs in all parts of São Tomé Island. The conservation assessment for $P$. margaritarius (Cumberlidge, 2008b) now needs to be revised in 
the light of the significant reduction in the extent of occurrence of this species from the whole of São Tomé Island (total area $836 \mathrm{~km}^{2}$ ) to $183 \mathrm{~km}^{2}$, which is just the northern part of this island (about 21\%). Attempts to collect freshwater crabs in the large rivers on the road to Santana in São Tomé were unsuccessful. The absence of crabs in the rivers in this area may be due to the presence of significant amounts of detergent in the river water in these locations that is added when people wash their clothes (Daniels, Pers. Observ.).

Remarks. Potamonautes margaritarius s. 1. was originally described in 1869 from a subadult female specimen (CW $33 \mathrm{~mm}$ ) from an unspecified part of the island of São Tomé (A Milne-Edwards, 1869). The female type of $T$. margaritaria is a dried specimen, so cheliped, sternal, gonopod, DNA, and living color characters are not available. The identification of $P$. margaritarius originally based on this female depended on characters of the anterolateral margin of the carapace, which was described as being finely toothed between the exorbital and epibranchial teeth, with the small teeth continuing along the margin posterior to the epibranchial tooth (Fig. 2A-C) (A. MilneEdwards, 1869; Rathbun, 1904; Bott, 1955). However, this character was found here to be variable, because specimens from both lineages from the northern and southern parts of São Tomé included individuals with either a finely serrated or a granulated anterolateral margin of the carapace. Immediately following a moult the anterolateral margin may be lined by teeth but these may well suffer wear and tear over time and become more granulated in appearance, making the carapace anterolateral margin an inconsistent diagnostic character.

Prior to this study only one species of freshwater crab was known to occur on São Tomé - Potamonautes margaritarius (A. Milne-Edwards, 1869) from an unknown locality on the island (A. Milne-Edwards, 1869; Rathbun, 1904; Bott, 1955). The two species of freshwater crabs from São Tomé recognized here care distinguished morphologically on the basis of adult male characters, and genetically on the basis of differences in DNA sequence data. However, it is not possible to distinguish between the two species of freshwater crabs from São Tomé based on comparison with the characters available from the dried subadult female type of $T$. margaritaria, because that specimen lacks important diagnostic features of the adult male sternum, adult male major cheliped, and adult male first and second gonopods. Furthermore, characters of subadult female specimens (such as those of the fe- male sternal openings) have never proven to provide reliable species-level identifications in potamonautids (Cumberlidge, 1999), even if it were possible to fold back the female abdomen of the brittle, dried type. Given that the two species in the present study morphologically both resemble the description of T. margaritaria in characters of the carapace, we are unable to assign unequivocally either of these lineages to $P$. margaritarius with any degree of certainty. Furthermore, it is likely that the type of P. margaritarius is resistant to DNA extraction because of its very old age and dried condition. We therefore propose to replace the unidentifiable name-bearing type of T. margaritaria by a neotype because we are unable to establish the taxonomic identity of $T$. margaritaria from the existing name-bearing type (i.e., its name has become a nomen dubium) (ICZN, $4^{\text {th }}$ Edition, Article 75.5). It is therefore necessary for taxonomic stability to determine a neotype for Thelphusa margaritaria A. MilneEdwards, 1869, because it is uncertain as to whether A. Milne-Edwards' specimen belongs to the northern or southern lineage. It is therefore important to designate a neotype for Thelphusa margaritaria A. Milne-Edwards, 1869 , to fix the identity of that species given the present recognition of the freshwater crab populations in southern São Tomé as a separate species ( $P$. saotome sp. nov.). Therefore we here designate a male (cw 45.6, cl 32.6, ch 14.4, fw $14.4 \mathrm{~mm}$ ) (SAM-A090176) collected from Santana (0.2512 N, 6.740567 E) (Figs. $5 \mathrm{~A}, 7 \mathrm{~A}-\mathrm{E})$ as the neotype. This specimen was collected alive, colour photographs were obtained, and tissue was preserved in $100 \%$ alcohol for genetic studies.

Before the study of Daniels and Klaus (2018) hardly any collections of freshwater crabs had been made from São Tomé following the relatively early discovery of the presence of these crustaceans from this island. Daniels and Klaus (2018: fig. 5) provided supporting molecular evidence for the present new treatment of $P$. margaritarius s. 1. as two valid species: a northern clade that contains all individuals here identified as $P$. margaritarius (78 specimens from nine new localities (Fig. 1)), and a southern clade that contains all individuals representing $P$. saotome sp. nov.. Daniels and Klaus (2018: fig. 5) also demonstrated that these two clades did not share any haplotypes and are unconnected on the haplotype network. Furthermore, their DNA sequence divergence was shown to be $4.92 \%$ Daniels and Klaus (2018). The subadult female specimen (cw 35 mm, CAS-IZ 188789.00) collected by J. P. Pio and R. B. Bell from a locality between Santa Louisa and Santa Adelaide in the northern part of São 
Tomé island $(0.27939 \mathrm{~N}, 6.64637 \mathrm{E})$ that was included as 'Potamonautes 2' in the molecular phylogenic study by Daniels et al. (2015) probably belongs to P. margaritarius, judging from its collection locality in the northern part of the island.

In addition to genetic characters, our species recognition and diagnoses of the two species of Potamonautes from São Tomé provided here relies also on a suite of other morphological characters of adult males including sternal, cheliped, and G1 characters (see Remarks for P. saotome sp.nov.). Morphologically, $P$. margaritarius can be distinguished from $P$. saotome sp. nov. as follows. The thoracic sternal sulcus $\mathrm{s} 3 / \mathrm{s} 4$ of P. margaritarius is faint and shallow (Fig. 2B) (vs. deep and complete in P. saotome sp. nov.(Fig. 4B)); the fixed finger (propodus) of the major cheliped of adult males of P. margaritarius has four large rounded molar teeth proximally (Fig. 3D) (vs. a cheliped propodus with several low teeth proximally in $P$. saotome $\mathrm{sp}$. nov. (Fig. 5D)); the G1 TA in P. margaritarius is slim and only slightly widened in the middle, and has a long tip (about $1 / 3$ the length of the TA) that is strongly

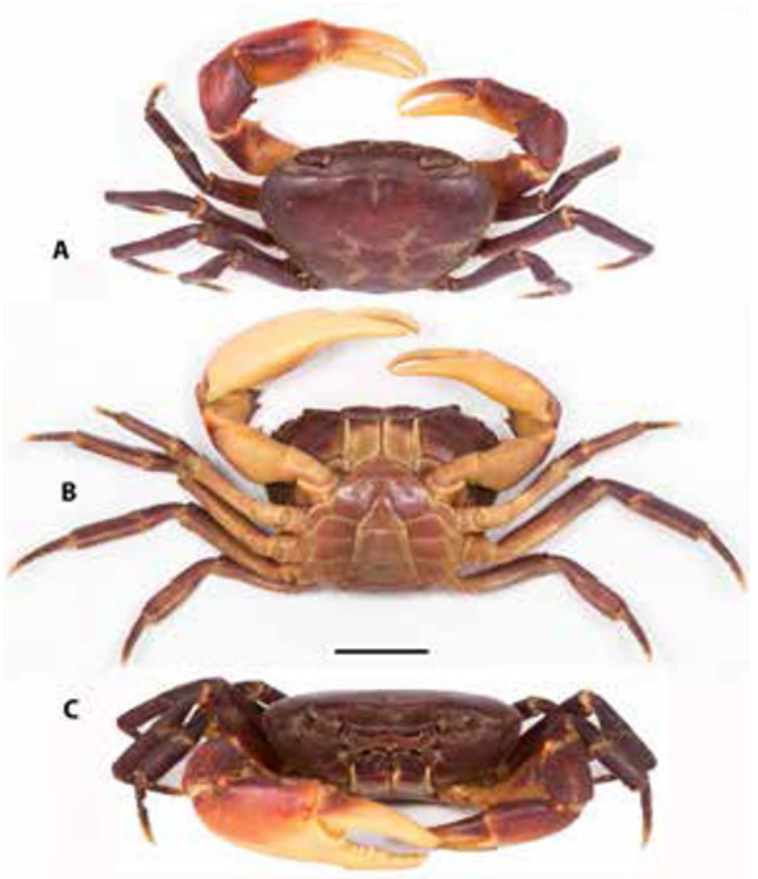

Figure 4. Potamonautes saotome sp. nov. Adult $\widehat{\partial}$, holotype, cw 35.8 mm (SAM-A090192), from Santa Catarina, São Tomé Island in the Democratic Republic of São Tomé and Príncipe. A, whole animal, dorsal view; B, whole animal, ventral view; C, whole animal, frontal view. Photographs by Theo Busschau, Stellenbosch University, South Africa. upcurved (Figs. 3A-B) (vs a G1 TA that is distinctly widened in the middle with a short tip (1/4 the length of the TA) that is only weakly upcurved in $P$. saotome sp. nov. (Figs. 5A-B); and the color of the carapace and branchiostegal walls of $P$. margaritarius are dark red-brown (vs. light brown in P. saotome sp. nov.).

Potamonautes saotome Cumberlidge and Daniels, sp. nov.

(Figs. 1, 4, 5, Tables 1, 2)

Material examined. Holotype (here designated). São Tomé Island, Democratic Republic of São Tomé and Príncipe: đđ (cw 35.3, cl 25.7, ch 11.9, fw 11.9 mm), SAM-A090192. São Tomé: Santa Catarina (0.232267 N, 6.478467 E), $120 \mathrm{~m}$ asl, coll. S. R. Daniels and T. Busschau, 7.vii.2017.

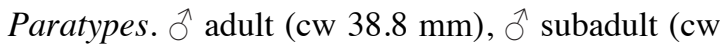
$34.5 \mathrm{~mm}$ ), 5 우 adults (cws 43.0, 38.4, 38.3, 38.1, 37.2 ovigerous) (SAM-A090193), same data as holotype.

Additional material examined. São Tomé Island, Democratic Republic of São Tomé and Príncipe: $5 \hat{\jmath} \widehat{\partial}$ subadults (cws 27.5, 25.0, 22.5, 22.5, $19.6 \mathrm{~mm}$ ), ㅇ subadult (cw $29.1 \mathrm{~mm}$ ) (SAM-A090188), São João dos Angolares (0.1303 N, 6.640067 E), 93 m asl, coll. S.R. Daniels and T. Busschau, 5.vii.2017. 4 $\widehat{\partial}$ subadults (cws 24.2, 26.8, 17.5, $17.0 \mathrm{~mm}$ ), $q$ subadult (cw $25.4 \mathrm{~mm}$ ) (SAM-A090189), Monte Mário (0.075683 N, 6.564017 E), $74 \mathrm{~m}$ asl, coll. S. R. Daniels and T. Busschau, 5.vii.2017. 6 ภे subadults (cws 28.0, 25.5, 23.8, 20.0, 19.9, $17.3 \mathrm{~mm}$ ), q subadult (cw $30.0 \mathrm{~mm}$ ) (SAM-A090190), Porto Alegre (0.044917 N, 6.54285 E), $41 \mathrm{~m}$ asl, coll. S. R. Daniels and T. Busschau, 5.vii.2017. $2 \widehat{\jmath}$ subadults (cws $31.7,32.0 \mathrm{~mm}$ ), 4 우 adults (cws 41.9, 41.0, 40.1, 36.1 mm), $\varnothing$ subadult (cw $30.0 \mathrm{~mm}$ ) (SAM-A090187), Santa Cecelia (0.1793 N, 6.682167 E), $44 \mathrm{~m}$ asl, coll. S. R. Daniels and T. Busschau, 7.vii.2017.

Diagnosis. Thoracic sternal sulcus $\mathrm{s} 3 / \mathrm{s} 4$ shallow faint, not completely crossing thoracic sternum (Fig. 4B); third maxilliped ischium smooth, lacking conspicuous sulcus (Fig. 5 A-B); cheliped merus with large pointed distal meral tooth otherwise both lower margins smooth (Fig. 4B); G1 TA short (TA/SS 0.45), slim, basal third straight, curving outward at 45 degree angle to axis of gonopod, midsection slightly widened medially, with terminal third long, distinctly upcurved (Figs. 5A-B).

Description. Carapace (Figs. 4A-C): surface smooth; flat $(\mathrm{ch} / \mathrm{fw} 1.0)$; postfrontal crest distinct, 


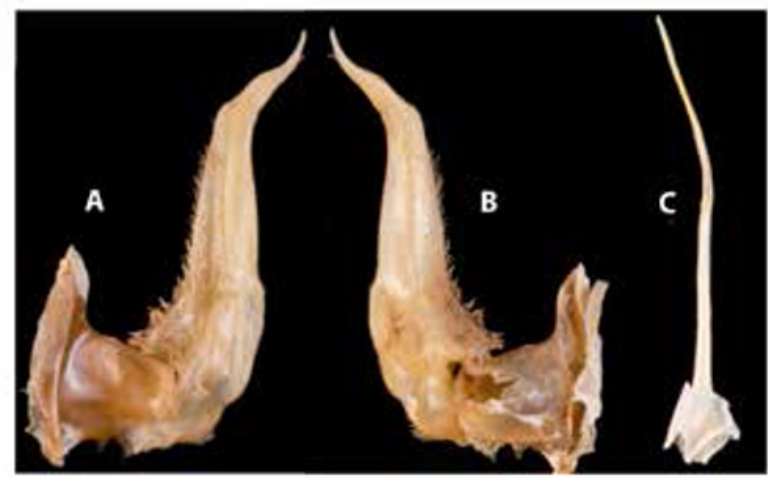

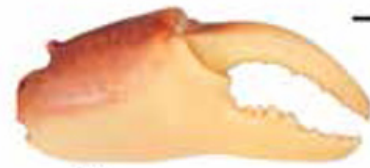

D

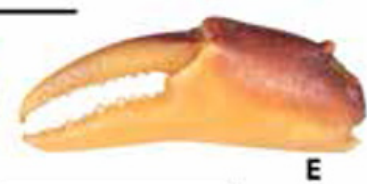

E

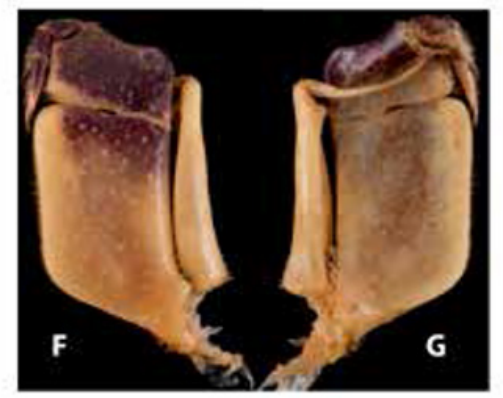

Figure 5. Potamonautes saotome sp. nov. Adult $\hat{\jmath}$, holotype, cw 35.8 mm (SAM-A090192), from Santa Catarina, São Tomé Island in the Democratic Republic of São Tomé and Príncipe. A, left G1 ventral view, B left G1 dorsal view, C, left G2 ventral view. D, right cheliped, frontal view; E, left cheliped, frontal view; $\mathrm{G}$, left third maxilliped, frontal view; $\mathrm{H}$, left third maxilliped, posterior view. Photographs by Theo Busschau, Stellenbosch University, South Africa. Scale bar $4.7 \mathrm{~mm}(\mathrm{~A}-\mathrm{C})$, $14.3 \mathrm{~mm}(\mathrm{D}, \mathrm{E}), 3.6 \mathrm{~mm}(\mathrm{~F}-\mathrm{H})$.

completely crossing carapace; exorbital, epibranchial teeth each reduced to small granule; anterolateral margin granulated between exorbital, epibranchial teeth; anterolateral margin behind epibranchial tooth lined by series of small teeth; semicircular, urogastric, cardiac, branchial grooves deep; cervical groove deep near semicircular groove, fading toward postfrontal crest; groove between epigastric crests long, forked posteriorly; front broad (fw/cw 0.35), strongly deflexed; branchiostegal wall divided by pleural (vertical) suture, epimeral (longitudinal) suture into three regions, all smooth; suborbital margin granulated. Third maxilliped (Figs. 5G-H): exopod with long flagellum, ischium smooth lacking sulcus. Epistomial tooth: large, triangular, margins granulated. Mandible: palp two-segmented; terminal segment simple. Thoracic sternum (Fig. 4B): s2/s3 deep, horizontal, completely crossing sternum; s3/ s4 shallow, faint, not completely crossing thoracic sternum; margins of s4 low, not raised. Cheliped (Fig. 5D): dactylus (moveable finger) slim, highly arched, enclosing oval interspace, one medium tooth in midsection, other teeth small; propodus (fixed finger) with two large molars proximally; carpus distal tooth large, pointed, proximal tooth subequal, pointed; merus inferior margins both smooth, distal meral tooth large, pointed; p2-p5 slim. Pleon (Fig. 4): wide, triangular, telson (a7) triangular, with rounded apex, indented sides. Gonopods (Figs. 5A-C): G1 TA: short (TA/SS 0.45), slim, basal third straight, curving outward at 45 degree angle to axis of gonopod, midsection slightly widened medially, with terminal third long, distinctly upcurved; G2 TA: long (TA/SS 0.57), flagellum-like. Adults (judged by size at pubertal moult) beginning around cw $36 \mathrm{~mm}$ in both sexes.

Coloration. Dorsal carapace, branchiostegal walls, dark red-brown, cheliped dactylus, propodus white except for red-brown dorsal margin, thoracic sternum light brown.

Distribution. Potamonautes saotome sp. nov. is endemic to the southern parts of São Tomé Island and has been recorded from five localities between 93 and $120 \mathrm{~m}$ asl. The known distribution of $P$. saotome sp. nov. is shown in Fig. 1 and is based on the georeferenced localities of a subset of the specimens collected by Daniels and Klaus (2018: table 1). The range of this species, expressed as the extent of occurrence (EOO) is $289 \mathrm{~km}^{2}$ (about a third of the island), and the area of occupancy (AOO) is estimated to be around $20 \mathrm{~km}^{2}$. The specimen identified in Rathbun (1904) as P. margaritarius from Ilhéu das Rolas, a small island south of São Tomé separated by a few kilometers of sea (the Canal das Rola) most likely belongs to this species instead based on its extreme southern locality.

Ecological notes. This species lives in burrows dug into the banks of clear water streams and rivers. This species occurs at lower altitudes at elevations 93-120 $\mathrm{m}$ asl, in closed-canopy primary forests and disturbed secondary forests. Most details of its ecology are unknown.

Haplotype. The specimens assigned to $P$. saotome sp. nov. in this study correspond to the Southern clade in the maximum clade credibility tree for $P$. margaritarius s. 1. based on $102 \mathrm{CO} 1$ sequences shown 
in Daniels and Klaus (2018: fig. 3), and contains all individuals from the southern part of São Tomé.

Conservation status. An IUCN extinction risk assessment of $P$. saotome sp. nov. has not yet been carried out. However, given the fact that this species is known from 39 specimens from five localities, including some in a protected area (the Ôbo National Park), and that there are no known immediate threats, this species would probably be regarded as Least Concern (LC).

Etymology. This species is named for São Tomé Island, which is the only place where it is found. The name is used as a noun in apposition.

Potamonautes príncipe Cumberlidge, Clark and Baillie, 2002

(Figs 1, 6, 7, Table 1)

Potamonautes príncipe Cumberlidge, Clark and Baillie, 2002: 13-17, figs. 1-2; Cumberlidge 2008c: 1-3.

Material examined. All specimens were collected from Príncipe Island, Democratic Republic of São Tomé and Príncipe. Holotype: NHML 2001.6907, ㅇ adult, (cw 40.5, cl 27.5, ch 14.8, fw $10.5 \mathrm{~mm}$ ), summit of Pico do Príncipe, (1.585917 N, 7.3825 E), 945 m asl, coll. J. E. M. Baillie, 26 Sept. 1999.

Paratype: $q$ subadult (cw 33.2, cl 22.8, ch 11 .6, fw $10.0 \mathrm{~mm}$ ) (NHML 2001.6908), summit of Pico do Príncipe (1.585917 N, 7.3825 E), 945 m asl, coll. J. E. M. Baillie, 1.ix.1999.

Additional material examined: 今 adult (cw 35.0, cl 24.7, ch 12.7, fw $11.5 \mathrm{~mm}$ ) (SAM-A090195) from Picão. 7ठ̂ (cws 31.5, 30.6, 30.9, 29.7, 27.5, 24.5, $15.8 \mathrm{~mm}$ ) (SAM-A090194), Praia Campanha stream, Makarra Lodge locality (1.682933 N, 7.422933 E), 38 $\mathrm{m}$ asl, sympatric with sesarmids, coll. S. R. Daniels,

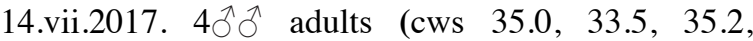
$23.8 \mathrm{~mm}$ ), ㅇ adult (cw $36.1 \mathrm{~mm}$ ) (SAM-A090195), Picão (1.668967 N, 7.433083 E), $73 \mathrm{~m}$ asl, seepage under rocks, no flowing water, coll. S. R. Daniels, 15.vii.2017. 5ð subadults (cws 29.5, 28.2, 26.2, 24.5, $22.9 \mathrm{~mm}$ ), ㅇ subadult (cw $26.0 \mathrm{~mm}$ ), juvenile (cw $12.6 \mathrm{~mm}$ ) (SAM-A090196), Santo António (1.646267 N, 7.419567 E), $74 \mathrm{~m}$ asl, from under rocks in small stream, coll. S. R. Daniels, 15.vii.2017. 4 (cws 33.2, 26.7, 25.3, $22.2 \mathrm{~mm}$ ), ㅇ subadult (cw $32.8 \mathrm{~mm}$ ), juvenile (cw $19.6 \mathrm{~mm}$ ) (SAM-A090197), Ciabaa (1.688133 N, 7.41195 E), $39 \mathrm{~m}$ asl, from small stream at cliff near fishing village, coll. S. R. Daniels, 16.vii.2017. 7 (cws 35.2, 30.4, 17.6, 15.6, 18.3, 17.0, $16.5 \mathrm{~mm}$ ), q subadult (cw $33.9 \mathrm{~mm}$ ) (SAM-A090199), Cascada, Ôbo National Park (1.585917 N, 7.4219 E), $141 \mathrm{~m}$ asl, coll. S. R. Daniels, 17.vii.2017. $4 \hat{\jmath}$ (cws 33.5, 30.3, 24.5, $15.1 \mathrm{~mm}$ ), 2 ㅇ subadults (cw 33.3, $24.1 \mathrm{~mm}$ ) (SAM-A090199), Cascada, Ôbo National Park (1.585917 N, 7.4219 E), $141 \mathrm{~m}$ asl, coll. S. R. Daniels, 18.vii.2017. 50 (cws 30.8, 27.7, $18.9,17.8,19.2 \mathrm{~mm}$ ), subadult female (cw $33.1 \mathrm{~mm}$ ) (SAM-A090198), Roca Infante, north of Rio da Ponte Grande (1.597817 N, 7.416967 E), 154 m asl, coll. S. R. Daniels, 18.vii.2017.

Diagnosis. Carapace (Figs. 6A-C): Postfrontal crest straight, smooth, spanning entire carapace, ends meeting anterolateral margins at epibranchial teeth; exorbital tooth small, pointed; epibranchial tooth represented only by small granule; anterolateral margin posterior to epibranchial tooth raised, completely smooth, continuous with posterolateral margin. Carapace surface completely smooth; slightly arched, height greater than front width (ch/fw 1.1). Pleural (vertical) suture on carapace branchiostegite Y-shaped, ends meeting exorbital, epibranchial teeth (Fig. 6B). Suborbital margin raised, completely smooth. Ischium of third maxilliped with deep vertical sulcus. Thoracic sternum (Fig. 6C): third sternal sulcus s3/s4 deep, $\mathrm{v}$-shaped, meeting rim of sternopleonal cavity but not the sternopleuronal cavity itself; thoracic episternal sulci s4/e4, s5/e5, s6/e6, s7/e7 distinct. Cheliped (Figs. 7D-E): anterior inferior margin of cheliped merus lined by row of small sharp teeth, with large pointed distal meral tooth near junction with carpus (Fig. 6C); major cheliped propodus inferior margin longer than cw. Gonopods (Figs. 7A-B): G1 TA: short (TA/SS 0.32 ), about one-third length of SS), straight (in line with longitudinal axis of gonopod), conical, tapering to broad tip.

Redescription. Redescription based on $\delta$ adult (cw 35.0, cl 24.7, ch 12.7, fw $11.5 \mathrm{~mm}$ ) (SAM-A090195). Carapace (Figs. 6A-C): ovoid, wide (cw/fw 3.88), slightly arched (ch/fw 1.1); surface completely smooth semi-circular, urogastric, transverse branchial groove faint; front straight, relatively narrow, about onequarter $\mathrm{cw}$ (fw/cw 0.26); postfrontal crest distinct, smooth, straight, spanning entire carapace, ends meeting anterolateral margin at epibranchial teeth; anterolateral margin between exorbital, epibranchial teeth smooth; anterolateral margin posterior to epibranchial tooth raised, completely smooth, continuous with posterolateral margin; exorbital tooth small, pointed; epibranchial tooth represented only by 
small granule; suborbital margin raised, completely smooth; branchiostegite divided by two sutures (pleural (vertical), epimeral (longitudinal)) into three regions, all smooth. Thoracic sternum (Fig. 6B): s1/s2 deep; s2/s3 deep, running horizontally across sternum; s3/s4 deep, v-shaped, complete, meeting rim of sternopleonal cavity but not the sternopleuronal cavity itself; s4/e4, s5/e5, s6/e6, s7/e7 all distinct. Third maxillipeds (Fig. 7G-H): filling entire oral field, except for transversely ovate respiratory openings at superior lateral corners; exopod with long flagellum; ischium with deep vertical sulcus. Epistomial tooth (Fig. 6C): prominent, granulated, v-shaped. Mandibular palp: two-segmented; terminal segment single, undivided, with setae (but no hard flap) at junction between segments. Cheliped (Figs D-E): dactylus (moveable finger) slim, highly arched, enclosing oval interspace, one medium tooth in mid-section, other
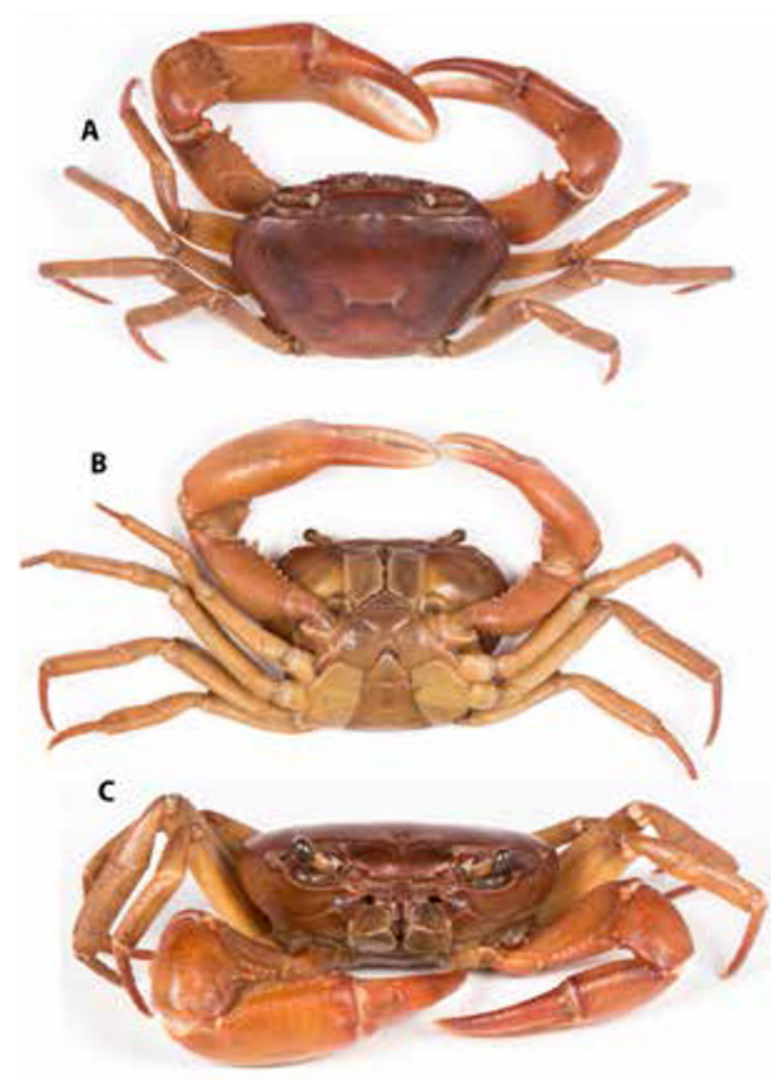

Figure 6. Potamonautes principe. Adult $\hat{\sigma}$, cw $35.0 \mathrm{~mm}$ from Picão, Príncipe Island, in the Democratic Republic of São Tomé and Príncipe (SAM-A090195). A, whole animal, dorsal view; B, whole animal, ventral view; $\mathrm{C}$, whole animal, frontal view. Photographs by Theo Busschau, Stellenbosch University, South Africa. teeth small; propodus (fixed finger) with two large molars proximally; propodus inferior margin longer than cw, carpus distal tooth large, pointed, proximal tooth half size of distal tooth, pointed; merus medial inferior margin with row of small sharp teeth along entire length, large pointed tooth at distal end, lateral inferior margin smooth; superior surface of merus smooth. Pereiopods p2-p5 (Figs. 6A-B): slender, p3 longest, p5 shortest, dactyli of p2-p5 tapering to point, each bearing four rows of downward-pointing short, sharp spines. Pleon (Fig. 6B): male slim, triangular, telson (a7) narrow triangle with rounded apex; female subcircular, segments al-a6 quadrate, telson (a7) broad triangle with rounded apex. Gonopods (Figs. 7A-C): G1 TA: short (TA/SS 0.32), about one-third length of SS), straight (in line with longitudinal axis of gonopod), conical, tapering to broad tip; G2 TA: medium length (TA/SS 0.41), flagellum-like. Medium sized species, adults beginning around $\mathrm{cw} 40 \mathrm{~mm}$. Carapace, legs of freshly caught specimens purple with creamy white underparts.

Distribution. This species is endemic to Príncipe Island and is known to occur in eight localities ranging from $38 \mathrm{~m}$ asl to the summit of the Pico de Príncipe (945 m asl) (Cumberlidge et al., 2002). The extent of occurrence (EOO) calculated using GeoCat (Bachman et al., 2011) is $37.8 \mathrm{~km}^{2}$, and the area of occupancy (AOO) is estimated as $28 \mathrm{~km}^{2}$. The updated distribution of $P$. principe is shown in Fig. 1 and includes the type locality and all of the georeferenced specimens collected by Daniels and Klaus (2018: table 1).

Ecological notes. The crabs reported on here were collected in lowland rainforest by hand from under boulders in streams, as well as from under logs and stones. Female crabs were frequently encountered in the forest under rocks and decaying logs some distance from rivers and streams. Interestingly, the female type specimens of $P$. principe were also collected from on land from under damp and decaying leaf litter in the cloud forest at the summit of the Pico do Príncipe (945 $\mathrm{m}$ asl) where the terrain is volcanic and mountainous, and the vegetation cover is cloud forest with small stunted trees, and a high abundance of epiphytes and bryophytes (Cumberlidge et al., 2002).

Conservation status. Potamonautes principe was listed as Data Deficient (DD) on the International Union for the Conservation of Nature Red list (Cumberlidge, 2008c; Cumberlidge et al., 2009) in view of the fact that this species was known at the time from only two specimens from a single locality. However, this conservation assessment now needs to be revised 
in the light of the present new material because the number of collection localities has expanded from one to eight, and the distributional range has grown from around $4 \mathrm{~km}^{2}$ to $37.8 \mathrm{~km}^{2}$ (about a third of the island).

Remarks. Perhaps surprisingly, given the location of Príncipe Island off the coast of Gabon in Central Africa, P. principe shares common ancestry with a large clade of species of Potamonautes from southern Africa (Daniels and Klaus, 2018: fig. 2). For example, the sister clade to $P$. principe includes species from South Africa (P. clarus Gouws, Stewart and Coke, 2000 and P. depressus (Krauss, 1843) from KwaZulu Natal, then P. mhlope Daniels, 2017, P. turkayi Wood and Daniels, 2017, P. brincki (Bott, 1960), P. parvicorpus Daniels, Stewart, Gouws, Cunningham and Matthee, 2002, and P. parvispina Stewart, 1997 from the Western Cape, then $P$. isimangaliso Peer, Perissinotto, Gouws and Miranda, 2015, P. lividus Gouws, Stewart and Reavell, 2001, and P. danielsi Peer, Gouws, Lazo-Wasem, Perissinotto and Miranda, 2017 from KwaZulu-Natal, followed by a clade with numerous species that range from the Northwest and Mpumalanga Provinces of South Africa to Mozambique, Zimbabwe, Angola, and Zambia (Daniels and Klaus, 2018: fig. 2). Interestingly, although there is little support from the phylogeny in Daniels and Klaus (2018: fig. 2) for the idea of Cumberlidge et al. (2002) that $P$. principe is most closely related to P. anchietae (Brito-Capello, 1871) from Angola (Bott, 1955; Cumberlidge and Tavares, 2006), there is at least a morphological similarity between the G1 TAs of these two taxa - both are short and cone-shaped (Figs. 7A-B; Bott, 1955: fig. 24).

Potamonautes príncipe does not have many extant relatives, because it is also not closely related to either of the species from São Tomé ( $P$. margaritarius and $P$. saotome sp. nov.) and these island species occupy separate lineages of the Afrotropical phylogenetic tree (Daniels and Klaus, 2018: fig. 2). For example, P. margaritarius is basal to the clade that contains the West and Central African species of Potamonautes, while $P$. principe is basal to the clade that contains the southern African species of Potamonautes (Daniels and Klaus, 2018: fig. 2).

The three species found on São Tomé and Príncipe can be distinguished from each other by the following characters. The G1 TA of both of the species from São Tomé (Figs. 3 A-B, 5 A-B) is long (TA/SS 0.45-0.48, almost half the length of the SS), angled at 45 degrees to the longitudinal axis of the gonopod, widened in the middle, and with a tip that is highly upcurved (vs.

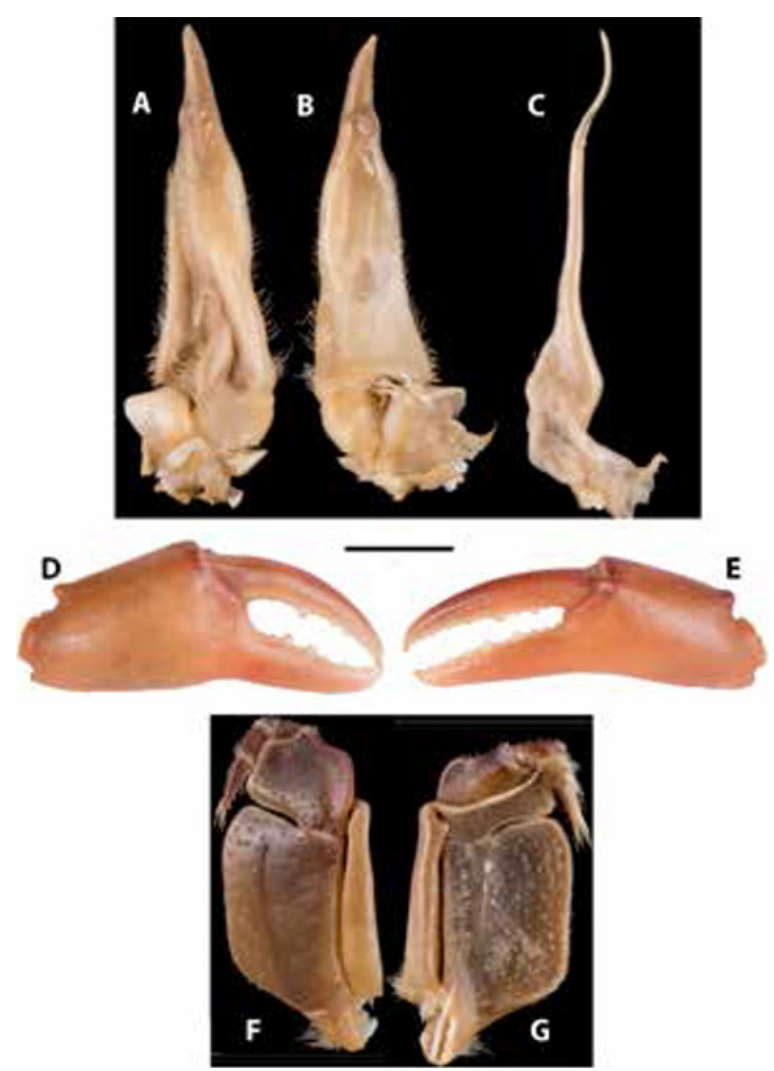

Figure 7. Potamonautes principe. Adult đo, cw $35.0 \mathrm{~mm}$ from Picão, Príncipe Island, in the Democratic Republic of São Tomé and Príncipe (SAM-A090195). A, left G1 ventral view, B left G1 dorsal view, C, left G2 ventral view. D, right cheliped, frontal view; E, left cheliped, frontal view; G, left third maxilliped, frontal view; $\mathrm{H}$, left third maxilliped, posterior view. Photographs by Theo Busschau, Stellenbosch University, South Africa. Scale bar $2.5 \mathrm{~mm}$ (A-C), $13.3 \mathrm{~mm}$ (D, E), 2.5 $\mathrm{mm}(\mathrm{F}-\mathrm{H})$.

short (TA/SS 0.32, about one-third the length of the SS), straight, in line with the longitudinal axis of the gonopod, conical, not widened in the middle, and with a straight tip in P. príncipe (Figs. 7 A-B). In addition, the carapace of both of the species from São Tomé is more flattened (ch/fw 1.0 in P. margaritarius and $P$. saotome sp. nov.) than in $P$. principe (ch/fw 1.1), the anterolateral margin of $P$. margaritarius and $P$. saotome sp. nov. is either finely toothed or granular behind the epibranchial tooth (Figs. 2A-B, 4 A-B) (vs a completely smooth margin in P. principe (Figs. 6A-B)), and the third maxilliped ischium of $P$. margaritarius is smooth and lacks a suture (Figs. 3G, 5G) (vs an ischium with a distinct vertical suture in $P$. príncipe (Fig. 7G)). 


\section{Discussion}

Daniels and Klaus (2018: fig. 3) demonstrated that the freshwater crabs on São Tomé actually represent two distinct species within Potamonautes and that these two species have distributional ranges that do not overlap (Fig. 1). Geographical isolation is the most likely mechanism of intra-island allopatric speciation within São Tomé given the relatively recent divergence times (Daniels and Klaus, 2018: fig. 3), and the low probability of gene flow between recently separated widely spaced populations that are genetically isolated by mountainous terrain.

Both P.margaritarius and P.principe were originally described from female specimens based on the distinct nature of their available morphological characters, and because at the time they were the first records of any species of freshwater crab from these remote islands (A. Milne-Edwards, 1869; Cumberlidge et al., 2002). The present redescriptions of these two taxa include for the first time the taxonomically important characters of the gonopods, chelipeds, abdomen, and sternum of adult male specimens.

\section{Habitat and ecology}

The volcanic oceanic islands of São Tomé and Príncipe that are home to P. margaritarius, P. saotome sp. nov., and $P$. principe lie in the São Tomé, Príncipe and Annobón Ecoregion (587) (Abell et al., 2005; Thieme et al., 2008). The habitats of this freshwater ecoregion where these species are found include mostly streams and swift rivers marked by waterfalls and rapids that flow into the Gulf of Guinea from perennial rivers that rise in the central highland mountains in São Tomé (highest 2,024 $\mathrm{m}$ asl) and Príncipe (highest $948 \mathrm{~m}$ asl) (Juste and Fa, 1994). The original vegetation of these islands was tropical rainforest (Juste and Fa, 1994) but now much of the lower-lying land is deforested and is used for agriculture. The remaining vegetation consists of lowland forests, montane rainforests, mossy forests, and mangrove forests that support a number of endemic and threatened species (Jones, 1994).

\section{Biogeographic considerations}

Oceanic islands of volcanic origin such as São Tomé and Príncipe that are separated from the mainland by deep seas are relatively uncommon in the Afrotropical region (Cumberlidge, 2008a; Daniels, 2011; Cumberlidge and Daniels, 2014). The fact that there are only a few species of freshwater crabs on two of these islands (but not on Annobón) perhaps reflects the strict ecological preference of primary freshwater crabs (see Yeo et al., 2014) for freshwater habitats (they are never found naturally in water with even low levels of salt), and saltwater is typically an effective barrier to their dispersal. The presence of primary freshwater crabs on oceanic islands such as these and other islands around the world is usually explained by a transoceanic dispersal event across the saltwater barrier (Rodríguez and López, 2003; Cumberlidge, 2008a; Cumberlidge and Ng, 2009; Yeo et al., 2008; Cumberlidge et al., 2009; Klaus et al., 2009; Klaus et al., 2010; Jesse et al., 2010). While such events are plausible, they are no doubt extremely rare, and may have involved the accidental displacement of ovigerous female freshwater crabs into the ocean (perhaps during a powerful storm). Crabs clinging to floating vegetation carried out to sea by surface currents could conceivably have crossed either the $225 \mathrm{~km}$ or $240 \mathrm{~km}$ of ocean necessary to reach São Tomé or Príncipe respectively from the African mainland. Esser and Cumberlidge (2011) provided experimental support for the feasibility of transoceanic dispersal hypotheses by demonstrating that species of potamid and gecarcinucid freshwater crabs from Thailand can indeed survive extended saltwater exposure, at least for two weeks or so. On the other hand, the presence of freshwater crabs on continental shelf islands such as Bioko presents fewer difficulties and is usually explained by conventional overland dispersal during past periods of lower sea levels when these islands were continuous with the mainland (Cumberlidge, 2008a).

The molecular phylogeny of Daniels and Klaus (2018: fig. 2) supports the hypothesis that the ancestors of $P$. margaritarius and $P$. principe reached their respective islands of São Tomé and Príncipe by two separate colonization events from the mainland. The distinctly separate lineages occupied by $P$. margaritarius and $P$. saotome sp. nov. and $P$. principe means that there is no support for a single invasion from the mainland that was later followed by a second dispersal event across $140 \mathrm{~km}$ of open ocean to reach the other island. Daniels and Klaus (2018: fig. 2) also timed the colonization events by freshwater crabs to São Tomé and Príncipe. Daniels and Klaus (2018) estimated the divergence of the freshwater crabs found on these two islands from their closest continental relatives in a Central / West African ancestral population to be 34-20 MYA (Oligocene/late Eocene to Early Miocene for $P$. margaritarius (including $P$. saotome sp. nov.)), and 
26-15 MYA (Late Oligocene to Middle Miocene for P. principe). The timing of the separate dispersals of populations of freshwater crabs from the mainland to these two islands must take into account the different ages of these two volcanic islands (Príncipe, $31 \mathrm{MY}$; São Tomé, 15-13 MY, Table 1), and the much younger estimated times to the most recent common ancestor (tMRCA) for these different crabs in the Pleistocene ( $P$. margaritarius (including $P$. saotome sp. nov.), 1.49-0.5 MYA; P. principe, 0.39-0.1 MYA) (Daniels and Klaus, 2018: fig. 2). It is possible that the recent estimates for the tMRCAs may be the result of extreme genetic bottlenecks given the active volcanic nature of these islands in the past, and this would leave open the possibility that these species might have arrived on these islands earlier than these dates.

\section{Acknowledgements}

The Department of Botany and Zoology, University of Stellenbosch is thanked for logistic support. Theo Busschau is thanked for helping to sample freshwater crabs on São Tomé Island and for taking all of the photographs used in this work. We thank the National Research Foundation incentive funding for financial support to the second author. We are grateful to Mr. Arlindo Carvalho for issuing an export permit for the freshwater crabs from São Tomé. Miss Estrela Matilde is thanked for her kindness and passion for biodiversity research, and for helping the second author with transport on Príncipe Island, and Ricardo Lima is thanked for helping with the logistic support. Three reviewers provided useful and constructive comments which we highly appreciate. Finally, we are very grateful to Paula Martin-Lefevre (MNHN, Paris) for providing collection details of the dried female type specimen of T. margartaria A. MilneEdwards, 1869.

\section{References}

Abell R, Thieme ML, Revenga C, Bryer M, Kottelat M, Bogutskaya N, Coad B, Mandrak N, Balderas SC, Bussing W, Stiassny MLJ, Skelton P, Allen GR, Unmack P, Naseka A, Ng R, Sindorf N, Robertson J, Armijo E, Higgins JV, Heibel TJ, Wikramanayake E, Olson D, Lopez HL, Reis RE, Lundberg JG, Sabaj Perez MH, Petry P. 2008. Freshwater Ecoregions of the World: A New Map of Biogeographic Units for Freshwater Biodiversity Conservation. BioScience 58: 403-414.

Bachman S, Moat J, Hill AW, de Torre J, Scott, B. 2011. Supporting Red List threat assessments with GeoCAT: Geospatial conservation assessment tool. ZooKeys 150: 117-126.

Balss H. 1914. Decapode Crustaceen von den Guinea-Inseln, Süd-Kamerun und dem Congogebiet. Ergebnisse der zweiten Deutschen Zentral-Afrika-Expedition 1910-1911, 1(Zool.): 97-108.
Bell RC, Drewes RC, Channing A, Gvozdik V, Kielgast J, Lotters S, Stuart BL, Zamudio KR. 2015. Overseas dispersal of Hyperolius reed frogs from Central Africa to the islands of São Tomé and Príncipe. Journal of Biogeography 42: $65-75$.

Bott R. 1955. Die Süßwasserkrabben von Afrika (Crust., Decap.) und ihre Stammesgeschichte. Annales du Musée du Congo belge, (Tervuren, Belgique) C-Zoologie, Serie 3(3): 209-352.

Bott R. 1960. Crustacea (Decapoda): Potamonidae, pp. 13-18. In: Hansström B (Editor). South African Animal Life. Results of the Lund University Expedition in 1950-1952.

Bott R. 1970. Betrachtungen über die Entwicklungsgeschichte und Verbreitung der Süßwasser-Krabben nach der Sammlung des Naturhistorischen Museums in Genf/Schweiz. Revue suisse de Zoologie 77(2):327-344.

Brito-Capello, F. de. 1871. Algumas especies novas ou pouco conhecidas de crustaceos pertencentes dos generos Calappa e Telphusa. Jornal de Sciencias mathematicas, physicas $e$ naturaes, Lisboa 3: 128-134.

Chace FA. 1942. Scientific results of a fourth expedition to forested areas in eastern Africa, III: Decapod Crustacea. Bulletin of the Museum of Comparative Zoology, Harvard College 91(3): 185-233.

Cumberlidge N. 1999. The freshwater crabs of West Africa, family Potamonautidae. Collection Faune et Flore Tropicales Vol. 36. Orstom, Paris.

Cumberlidge N. 2008a. Insular species of Afrotropical freshwater crabs (Crustacea: Decapoda: Brachyura: Potamonautidae and Potamidae) with special reference to Madagascar and the Seychelles. Contributions to Zoology 77: 71-81.

Cumberlidge N. 2008b. Potamonautes margaritarius. The IUCN Red List of Threatened Species 2008: e.T134918A4036007. http://dx.doi.org/10.2305/IUCN.UK.2008.RLTS. T134918A4036007.en. Downloaded on 03 April 2018.

Cumberlidge N 2008c. Potamonautes principe. The IUCN Red List of Threatened Species 2008: e.T134713A4002469. http://dx.doi.org/10.2305/IUCN.UK.2008.RLTS T134713A4002469.en. Downloaded on 03 April 2018

Cumberlidge N. 2011. Chapter 6. The status and distribution of freshwater crabs, pp. 71-78. In: Brooks EGE, Allen DJ, Darwall W.RT (Compilers). The Status and Distribution of Freshwater Biodiversity in Central Africa. Gland, Switzerland and Cambridge, UK: IUCN: i-ix+140pp.

Cumberlidge N, Daniels SR. 2014. Recognition of two new species of freshwater crabs from the Seychelles based on molecular evidence (Potamoidea: Potamonautidae). Invertebrate Systematics 28: 17-31.

Cumberlidge N, Ng PKL. 2009. Systematics, evolution, and biogeography of the freshwater crabs. Pp. 491-508 in: Martin JW, Crandall KA, Felder DL. eds. Crustacean Issues 18: Decapod Crustacean Phylogenetics. (Taylor \& Francis/ CRC Press: Boca Raton, Fl.).

Cumberlidge N, Tavares M. 2006. Remarks on the freshwater crabs of Angola, southwestern Africa, with the description of Potamonautes kensleyi, new species (Brachyura: Potamoidea: Potamonautidae). Journal of Crustacean Biology 26: 248-257.

Cumberlidge N, Clark PF, Baillie J. 2002. A new species of freshwater crab (Brachyura: Potamoidea: Potamonautidae) from Príncipe, Gulf of Guinea, Central Africa. Bulletin of the 
British Museum of Natural History (Zoology), London 68: 13-18.

Cumberlidge N, Ng PKL, Yeo DCJ, Magalhaes C, Campos MR, Alvarez F, Naruse T, Daniels SR, Esser LJ, Attipoe FYK, Clotilde-Ba FL, Darwall W, McIvor A, Ram M, Collen B. 2009. Freshwater crabs and the biodiversity crisis: importance, threats, status, and conservation challenges. Biological Conservation 142: 1665-1673. doi:10.1016/j. biocon.2009.02.038

Daniels SR. 2017. Sympatric colour morphs or distinct taxa? Examining species boundaries among two South African freshwater crabs (Decapoda: Potamonautidae: Potamonautes MacLeay, 1838), with the description of a new species. Journal of Crustacean Biology 37: 723-731.

Daniels SR. 2011. Reconstructing the colonization and diversification history of the endemic freshwater crab (Seychellum alluaudi) in the granitic and volcanic Seychelles Archipelago. Molecular Phylogenetics and Evolution 61: 534-542. doi:10.1016/j.ympev.2011.07.015

Daniels SR, Klaus S. 2018. Divergent evolutionary origins and biogeographic histories of two freshwater crabs (Brachyura: Potamonautes) on the West African conveyer belt islands of São Tomé and Príncipe. Molecular Phylogenetics and Evolution 127: 119-128.

Daniels SR, Phiri EE, Klaus S, Albrecht C, Cumberlidge N. 2015. Multilocus phylogeny of the Afrotropical freshwater crab fauna reveals historical drainage connectivity and transoceanic dispersal since the Eocene. Systematic Biology 64: 549-567.

Daniels SR, Stewart BA, Gouws G, Cunningham M, Matthee CA. 2002. Phylogenetic relationships of the southern African freshwater crab fauna (Decapoda: Potamonautidae: Potamonautes) derived from multiple data sets reveal biogeographic patterning. Molecular Phylogenetics and Evolution 25: 511-523.

De Man JG. 1914. Note sur quelques Crustacés décapodes brachyures. Annali del Museo civico di storia naturale di Genova (3)6(46): 122-138.

Esser L, Cumberlidge N. 2011. Evidence that salt water may not be a barrier to the dispersal of Asian freshwater crabs (Decapoda: Brachyura: Gecarcinucidae and Potamidae). The Raffles Bulletin of Zoology 59: 259-268.

Greef R. 1882. Die Land- und Süsswasser-Krebse der Inseln S. Thome und Rolas. Sitzungsberichte der Gesellschaft Beförderung der gesammten Naturwissenschaften in Marburg 1882(2): 25-27.

Greef R. 1884. Die Fauna der Guinea - Inseln S. Thome und Rolas. Sitzungsberichte der Gesellschaft Beförderung der gesammten Naturwissenschaften in Marburg 1884(2): 41-79.

Gouws G, Stewart BA, Coke M. 2000. Evidence for a new species of river crab (Decapoda, Brachyura, Potamonautidae) from the Drakensberg, South Africa. Journal of Crustacean Biology 20: 743-758.

Gouws G, Stewart BA, Reavell PE. 2001. A new species of freshwater crab (Decapoda: Potamonautidae) from the swamp forests of KwaZulu-Natal, South Africa: biochemical and morphological evidence. Crustaceana 74: 137-160.

Jesse R, Schubart CD, Klaus S. 2010. Identification of a cryptic lineage within Potamon fluviatile (Herbst) (Crustacea: Brachyura: Potamidae). Invertebrate Systematics 24: 348-
356. doi:10.1071/ IS10014

Jones PJ. 1994. Biodiversity in the Gulf of Guinea: an overview. Biodiversity and Conservation 3: 772-784. https://doi. org/10.1007/BF00129657

Juste BJ, Fa JE. 1994. Biodiversity conservation in the Gulf of Guinea Islands: Taking stock and preparing action (Jersey Wildlife Preservation Trust, Jersey, June 4-6, 1993). Biodiversity and Conservation 3(9): 759-771.

Klaus S, Brandis D, Ng PKL, Yeo DCJ, Schubart CD. 2009. Phylogeny and biogeography of Asian freshwater crabs of the family Gecarcinucidae (Brachyura: Potamoidea). Pp. 509-532 in: Martin JW, Crandall KA, Felder DL. eds. Crustacean Issues 18: Decapod Crustacean Phylogenetics. (Taylor \& Francis/CRC Press: Boca Raton, Fl.).

Klaus S, Schubart CD, Streit B, Pfenninger M. 2010. When Indian crabs were not yet Asian - biogeographic evidence for Eocene contact of India and Southeast Asia. BMC Evolutionary Biology 10: 287. doi:10.1186/1471-2148-10-287

Krauss CFF. 1843. Die Sudafrikanischen Crustaceen, p 37. Stuttgart,

Latreille PA. 1802. Histoire naturelle, générale et particulière, des Crustacés et des Insectes. Ouverage faisant suite a l'Histoire Naturelle générale et particuliere, composée par Leclerc de Buffon, et rédigé par C. S. Sonnini, membre de plusieurs Sociétés savantes. Familles naturelles des Genres, vol 3, Paris.

MacLeay WS. 1838. Brachyurous Decapod Crustacea. Illustrations of the zoology of South Africa; being a portion of the objects of natural history chiefly collected during an expedition into the interior of South Africa, under the direction of Dr. Andrew Smith, in the years 1834, 1835, and 1836; fitted out by "The Cape of Good Hope Association for Exploring Central Africa." In Smith A., Illustrations of the zoology of South Africa; consisting chiefly of figures and descriptions of the objects of natural history collected during an expedition into the interior of South Africa, in the years 1834, 1835, and 1836; fitted out by "The Cape of Good Hope Association for Exploring Central Africa.'(Invertebrates). Published under the Authority of the Lords Commissioners of Her Majesty's Treasury, Invertebratae. Smith, Elder and Co., London, [1849] IV: 53-71, pls 2, 3. [For dates of publication see Waterhouse 1880: 489-491].

Measey G J, Vences M, Drewes RC, Chiari Y, Melo M, Bourles B. 2007. Freshwater paths across the ocean: molecular phylogeny of the frog Ptychadena newtoni gives insight into amphibian colonization of oceanic islands. Journal of Biogeography 34: 7-20.

Milne-Edwards A. 1869. Révision du genre Thelphusa et description de quelques éspeces nouvelles faisant partie de la collection du Museum. Nouvelles Archives du Museum d'Histoire Naturelle, Paris 5: 161-190.

Milne-Edwards A. 1886. La description de quelques Crustacés du genre Thelphusa recueillis par M. De Brazza dans les regions du Congo. Bulletin de la Société philomathique de Paris 7(10): 148-151.

Milne-Edwards A. 1887. Observations sur les crabes des eaux douces de l'Afrique. Annales des sciences naturelles: Zoologie (7)4: 121-149.

Ng PKL, Guinot D, Davy P. 2008. Systema Brachyuorum: Part I. An annotated checklist of extant Brachyuran crabs of the world. The Raffles Bulletin of Zoology 17: 1-286. 
Ortmann AE. 1896. Das system der Decapoden-Krebse. Zoologische Jahrbucher Abteilung Für Systematik, Geographie und Biologie der Tiere 9: 409-453.

Ortmann AE. 1897. Carcinologische studien. Zoologische Jahrbucher (Systematics) 10: 256-372.

Ozorio B. 1887. Liste des Crustacés des possessions Portugaises d'Afrique occidentale, dans les collections du Museum d'Histoire Naturelle de Lisbonne. Jornal de Sciências, Mathemáticas, Physicas e Naturaes, Lisboa 11: 220-231.

Ozorio B. 1889. Nouvelle Contribution pour la Connaissance de la Faune Carcinologique des lles Saint-Thome et du Prince. Jornal de Sciências, Mathemáticas, Physicas e Naturaes, Lisboa (2)1: 129-139.

Ozorio B. 1892. Nova contribuigao para a fauna carcinologicac da Ilha de S. Thome. Jornal de Sciências, Mathemáticas, Physicas e Naturaes, Lisboa (2)2: 199-204.

Ozorio B. 1905. Uma nova Lista de Crustaceos Africanos. Jornal de Sciências, Mathemáticas, Physicas e Naturaes, Lisboa (62) 7: 149-150.

Peer N, Gouws G, Lazo-Wasem E, Perissinotto R, Miranda NA. 2017. Redescription of Potamonautes sidneyi (Rathbun, 1904) (Decapoda, Potamonautidae) and description of a new congeneric species from KwaZulu-Natal, South Africa. ZooKeys 657: 1-28.

Peer N; Perissinotto R, Gouws G, Miranda NAF. 201. Description of a new species of Potamonautes MacLeay, 1838, from the iSimangaliso Wetland Park, South Africa. ZooKeys 503: 23-43.

Rathbun MJ. 1900. The Decapod Crustaceans of West Africa. Proceedings of the U.S. National Museum 22: 221-316.

Rathbun MJ. 1904. Les crabes d'eau douce (Potamonidae). Nouvelles Archives du Museum d'Histoire Naturelle, Paris 4(6): 225-312.

Rathbun MJ. 1905. Les crabes d'eau douce (Potamonidae). Nouvelles Archives du Museum d'Histoire Naturelle, Paris 4(7):159-322.

Rodríguez G, López B. 2003. Insular species of Neotropical freshwater crabs (Crustacea: Brachyura). Journal of Natural History 37: 2599-2614. doi:10.1080/00222930210155710

Stewart BA. 1997. Biochemical and morphological evidence for a new species of river crab Potamonautes parvispina sp. nov. (Brachyura: Potamonautidae). Crustaceana 70: 737-753.

Thieme ML, Abell R, Stiassny MLJ, Skelton P, Lehner B, Teugels GG, Dinerstein E, Kamdem Toham A, Burgess N, Olson D. 2005. Freshwater Ecoregions of Africa and Madagascar: a conservation assessment. Island Press, Washington DC, USA.

Wood LE, Daniels SR. 2017.Genetic and morphological evidence for a new mountain-living freshwater crab species (Decapoda: Potamonautidae: Potamonautes) from the Western Cape province of South Africa. Invertebrate Systematics 30: 219-230.

Yeo DCJ, Cumberlidge N, Klaus S. 2014. Preface-Freshwater Decapod Biology in the 21st Century. In: Yeo DCJ, Cumberlidge N, Klaus S (eds.) Advances in freshwater decapod systematics and biology. Crustaceana Monographs 19: 1-6.

Yeo DCJ, Ng PKL, Cumberlidge N, Magalhaes C, Daniels SR, Campos M. 2008. A global assessment of freshwater crab diversity (Crustacea: Decapoda: Brachyura). Hydrobiologia 595: 275-286. doi:10.1007/s10750-007-9023-3.
Received: 19 June 2018

Revised and accepted: 22 November 2018

Published online: 7 December 2018

Editor: R. Vonk 